\section{THE DISTINCTIONS BETWEEN INDEFINITE PRONOUNS AND INTERROGATIVE PRONOUNS IN THAI ${ }^{1}$}

\section{Roongaroon \\ Teekhachunhatean ${ }^{2}$}

\begin{abstract}
This article aims to present a study of the distinctions between two types of pronouns in Thai-indefinite pronouns and interrogative pronouns, which are homophonous and homographic but different in function. The results of the study reveal that they can be distinguished both syntactically and semantically. Therefore, they can be classified into two word classes.
\end{abstract}

\section{Introduction}

Indefinite pronouns and interrogative pronouns show a language phenomenon that words with the same form, such as /khraj/, /Raraj/ , /thiînăj/, /mîaràj/ , /jàanraj/, and /thâwràj/, can function differently when occurring in different syntactic contexts. Some examples are:

(1) a. indefinite pronoun

năy rîan níi khraj duu kô movie $C L$ this who see $A D V$ dâaj

can

'Anyone can see this movie.'

'I would like to express my gratitude to Professor Dr. Prenee Kullavanijaya for patiently editing this paper and giving valuable suggestions and comments.

${ }^{2}$ Assistant Professor, Department of Thai, Faculty of Humanities, Chiangmai University. b. interrogative pronoun

năy rîạ níi khraj dâaj duu bâạ movie $C L$ this who PAST see some

'Who has seen this movie?'

(2) a. indefinite pronoun

phanáknaan khon níi khâw maa

employee $C L$ this come

thamjaan tântè

work since when

chăn cam mâj dâaj lécw

I remember not can PAST

'I can't remember when this employee began working.'

b. interrogative pronoun

phanákıaan khon níi khâw maa

employee $C L$ this come

thamjaan tântè

work since when

' From when was this employee employed?'

(3) a. indefinite pronoun

thâa ca tham ?araj khว̌s hâj

if will do what let

jǔt khwaamthùuktôn pen làk

hold on rightness as principle

'Whatever you do, you should abide by rightness.'

b. interrogative pronoun

thâa thamjaan kàp khon camnuan

if work with people amount

mâak khun jǔt ?araj pen

many you hold on what as

làk

principle

'If you work with many people, by what principle do you abide?'

From the above examples, /khraj/, /miaràj/, / Raraj/ have the same form but differ in function, i.e., interrogative pronouns request information from the addressee, such as $/ \mathrm{khraj} /$ asking about a person, /mîaràj/ about time, and / Raraj/ about a thing. Indefinite pronouns, on the other hand, do not signify a question. 
Both pronouns share the same meaning of indefiniteness and seem as if they cannot be absolutely distinguished. Yet, they are recognized by native speakers as separate words. The researcher, therefore wanted to study the distinctions between these two types of pronouns.

\section{The aim of the study}

This article aims to present a study of the distinctions between the indefinite pronouns and interrogative pronouns that have the same form with the hypothesis that they can be classified into two word classes. The study consisted of 3 stages. The first was to search for words that have the aforementioned characteristics. The second was to investigate their context in order to infer both syntactic and semantic criteria to classify them into two word classes. The third was to identify each word in the data as to what class it belongs.

\section{Sources of data}

The data came from three sources: two novels, two books of general knowledge, and one general article, randomly picked from the $\mathrm{CU}$ electronic corpus. From the last corpus, 200 samples were taken.

\section{The characteristics of indefinite and interrogative pronouns}

Using data survey and literature review as guidelines, characteristics about these pronouns were designated:

4.1 consisting of a formal element/daj/ or/raj/

4.2 having indefinite meanings

4.3 occurring in the same position as nouns
4.4 functioning as nouns or noun complements

4.5 cannot be modified by adjectives

Based on the characteristics above, 25 homophonous and homographic pairs of indefinite and interrogative pronouns have been identified. They can be classified by meaning into 7 types as follows:

\begin{tabular}{|c|c|}
\hline $\begin{array}{l}\text { person } \\
\text { thing }\end{array}$ & $\begin{array}{l}\text { : phûudaj, khraj } \\
\text { : prakaandaj, sìndaj, } \\
\text { ?arai, kraraj }\end{array}$ \\
\hline place & : năj, thînăj, thîidaj \\
\hline time & : mîadaj, mîaraj, mîaràj \\
\hline manner & $\begin{array}{l}\text { : jàâraj, jannaj, naj, } \\
\text { chêndaj, chênraj }\end{array}$ \\
\hline $\begin{array}{l}\text { amount or } \\
\text { estimation }\end{array}$ & $\begin{array}{l}\text { : thâwdaj, thâwraj, } \\
\text { thâwràj, phiandaj, }\end{array}$ \\
\hline & 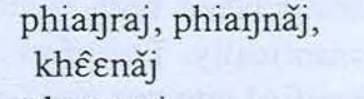 \\
\hline on & : thammaj \\
\hline
\end{tabular}

Mostly, these words consist of 2 morphemes. The former is a free morpheme with the meaning about human knowledge which Haspelmath (1997) called the ontological category. The ontological category is divided into 7 sub-groups : person, thing, place, time, manner, amount and reason. In some languages, the member of sub-groups can be lesser or greater. The other word is a bound morpheme with the meaning of indefiniteness: / daj/ and/raj/. It was noticeable that some words have undergone certain changes and become monosyllabic such as / khraj/ (khon+raj) and /năj/ (hǒn+raj); some with sound assimilation such as /janyaj/ (jàạ+raj) and /thammaj/ (tham+raj); some with sound attrition such as / ?araj/ ( an+raj) and /kraraj/ (kaan+raj); and some with tonal changes such as /thâwràj/ (thâw+raj), and /mîaràj/ (mîa+raj). 


\section{Syntactic contexts of indefinite and interrogative pronouns}

The researcher analyzed the 25 pairs of indefinite and interrogative pronouns in the sentential contexts to find out how different they were syntactically. Four criteria were used to separate these two types of pronouns.

5.1 Indefinite pronouns can occur with 3 types of noun modifier: numeral classifier, demonstrative modifier, and indefinite modifier. Interrogative pronouns, on the other hand, cannot occur in these contexts. Some examples are:

(4) a. indefinite pronoun pâa jàak ca phûu kàp Auntie want speak with khraj sàk khon nìn who $C L$ one

'Auntie would like to speak to someone.'

b. interrogative pronoun pâa jàak ca phûu kàp Auntie want speak with khraj who

'To whom would Auntie like to speak ?'

In example (4) a., / khraj/ is an indefinite pronoun that occurs before a numeral classifier, for example, /sàk khon nìn/, whereas in example (4) b., / khraj/ is an interrogative pronoun.

(5) a. indefinite pronoun

khăw chôsp rian ?araj thamnoon He like learn what manner nî

this

'He likes to learn things like this.'

b. interrogative pronoun

khăw chôop rian ?araj
He like learn what

'What did he enjoy studying?'

In example (5) a., / araj/ is an indefinite pronoun that occurs before a demonstrative phrase/thamnoon nii/, whereas in example (5) b., / $\mathrm{laraj} /$ is an interrogative pronoun.

(6) a. indefinite pronoun

samăj níi ?araj tàạtàay

period this what various

phátthanaa paj rûatrew mâak develop quickly very

'At present, everything is quickly developed.'

b. interrogative pronoun

samăj níi ?araj phátthanaa paj

period this what develop

rûatrew mâak

quickly very

'At present, what is quickly developed?'

In example (6) a., / 2 araj/ is an indefinite pronoun that occurs before an indefinite modifier /tàantàay/, whereas in example (6) b., /2araj/ is an interrogative pronoun.

5.2 Indefinite pronouns can occur as an object of a negated predicate. Interrogative pronouns, on the other hand, cannot occur in such context. Examples are:

(7) a. indefinite pronoun

mâj phóp phû:daj naj thâm nán

not see who in cave that

laəj

at all

'(I) didn't see anyone in that cave.'

b. interrogative pronoun

thâan phóp phû:daj naj thâm you see who in cave nán bâan

that some

'Whom did you see in that cave?' 
In example (7) a., /phû:daj/ is an indefinite pronoun occurs as an object of a negated predicate, /mâj phóp phû:daj/, whereas in example (7) b., / phû:daj/ is an interrogative pronoun and as seen in the sentence is not accepted if the predicate is negated.

5.3 Indefinite pronouns can occur in a yes-no question with $/ \mathrm{măj} /$, /rŭt/, / rütplàaw/. Interrogative pronouns, on the other hand, cannot occur in this context. Examples are given below:

(8) a. indefinite pronoun

hótdòk mii sìndaj kiàw khôn hotdog have what relate

kàp măa riǔplàaw

to dog or not

'Is 'hotdog' related to dogs in anyway?'

b. interrogative pronoun

hótdòk mii sìndaj kiàw khôn

hotdog have what relate

kàp măa

to $\quad d o g$

'Is 'hotdog' related to dogs?'

In example (8) a., /sìndaj/ is an indefinite pronoun that occurs in a yes-no question with /rütplàaw/, whereas example (8) b., with/sìndaj/ as an interrogative pronoun is already a question and obviously needs nothing more to make it so.

5.4 Indefinite pronouns can occur in a subordinate clause of a complex sentence as well as in a co-ordinate clause of a compound sentence. Interrogative pronouns, on the other hand, cannot occur in these contexts. Some examples are:

(9) a. indefinite pronoun

khraj thîi jạ mii panhăa who that still have problem

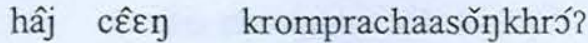

let inform The Public Welfare Department

'Anyone who has a problem, inform The Public Welfare Department'

b. interrogative pronoun dèk thîi maa chûaj raw sòn the boy that come help us deliver khวัon pen khraj

goods is who

'Who is the boy who helps us to deliver the goods?.

In example (9) a., / khraj/ is an indefinite pronoun occurring in a subordinate clause, whereas in example (9) b., /khraj/ is an interrogative pronoun occurring in a main clause.

(10) a. indefinite pronoun

thâa puu sìa lòn thîidaj, thîi

if spread mat down where, place nân pen ?anacàk khว̌ọ ton

that is territory of oneself 'Whenever one spreads his mat anywhere, that place becomes his territory.'

b. interrogative pronoun

thâa ca damnənkaan taam

if will implement according to khôsanวัว, rátthabaan ca nam the proposal, government will bring nóppramaan maa càak thîidaj budget from where

'If it is implemented according to the proposal, from where will the government get this budget?'

In example (10) a., /thîidaj/ is an indefinite pronoun occurring in a coordinate clause of a compound sentence, whereas in example (10) b., /thîidaj/ is an interrogative pronoun occurring in a main clause. 


\section{Semantic contexts of indefinite and interrogative pronouns}

The semantic properties of indefinite and interrogative pronouns were studied following Haspelmath (1997) and Lyons (1995). Four criteria were used to separate these two types of pronouns.

\subsection{Specificity}

The concept of specificity is a key concept in the semantics of reference. An expression is specific if the speaker presupposes the existence and unique identifiability of its reference. This criterion identifies interrogative pronouns from indefinite pronouns: the former occur in $[+$ specific $]$ context, while the latter occur in $[ \pm$ specific] context.

\subsection{Knowledge of the speaker} This criterion identifies interrogative pronouns from indefinite pronouns: the former occur in the context [-known to the speaker], while the latter occur in the context [ \pm known to the speaker].

\subsection{Negation}

This criterion identifies interrogative pronouns from indefinite pronouns: the former occur in the context [-negation], while the latter occur in the context [ \pm negation].

\subsection{Request for information}

This criterion applies only to interrogative pronouns. The communicative function of a question is to obtain information about facts relatively unknown to the speaker. This criterion identifies interrogative pronouns from indefinite pronouns: the former occur in the context [+request information], while the latter occur in the context [-request information].

From these 4 semantic criteria, indefinite pronouns and interrogative pronouns can be separated as seen in this chart:

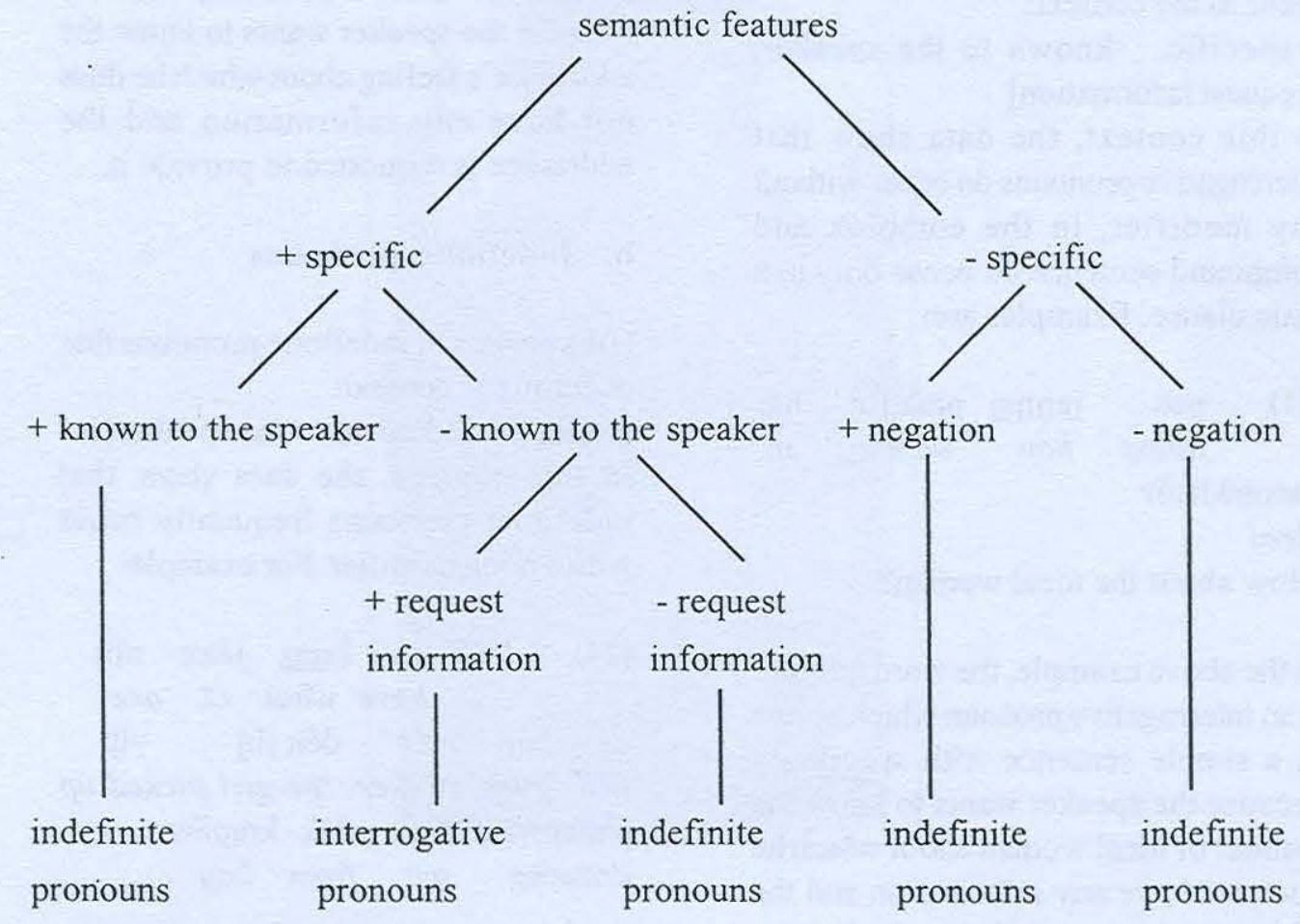


The above chart shows 5 of contexual meaning. Interrogative pronouns can occur in only one context, while indefinite pronouns can occur in four contexts. We may thus specify the semantic features of interrogative pronouns with 3 features [+specific, -known to the speaker, +request information]. For indefinite pronouns, we have 2 to 3 semantic features:

context 1: consists of 2 features [ + specific, + known to the speaker]

context 2: consists of 3 features

[+specific, -known to the speaker, -request information]

context 3: consists of 2 features [-specific, +negation]

context 4 : consists of 2 features

[-specific, - negation]

\section{a. Interrogative pronouns}

Examples of interrogative pronouns that occur in the context:

[+specific, -known to the speaker, +request information]

In this context, the data show that interrogative pronouns do occur without any modifier, in the complex and compound sentence do occur only in a main clause. Examples are:

$$
\begin{aligned}
& \text { pen jạnaj phûujīn naj } \\
& \text { about how woman in }
\end{aligned}
$$

?udomkhati?

ideal

'How about the ideal woman?'

In the above example, the word/janyaj/ is an interrogative pronoun which occurs in a simple sentence with specificity because the speaker wants to know the manner of ideal woman about which he does not have any information and the addressee is requested to provide it.
(12) săahèt thîi tham hâj cháan cause that make elephant

khâa khon maa càak sìndaj kill people come from what 'What is the cause of the elephant's killing people?'

In (12), the word /sìndaj/ is an interrogative pronoun that occurs in a complex sentence with specificity because the speaker wants to know the cause of the elephant's killing people about which he does not have any information and the addressee is requested to provide it.

khunmวัo rúusìk jàanraj mîa doctor feel how when cháa cht̂ak nii taaj paj elephant $C L$ this die

'Doctor, how did you feel when this elephant died?'

In (13), the word /jàayraj/ functions as an interrogative pronoun occurring in a compound sentence with specificity because the speaker wants to know the addressee's feeling about which he does not have any information and the addressee is requested to provide it.

\section{b. Indefinite pronouns}

(i)Examples of indefinite pronouns that occur in the context:

[+specific, + known to the speaker] In this context, the data show that indefinite pronouns frequently occur with a noun modifier. For example:

$$
\begin{aligned}
& \text { "nǔu mii ?araj jàan nìn } \\
& \text { I have what } C L \text { one }
\end{aligned}
$$

ca hâj mêع" dèk jīn yìp will give mother the girl picked up phâapwâat 2jok càak krapăw

drawing out from bag 
"I have something to give to you, Mommy" The girl took a drawing from her bag.

In (14), the word / $\mathrm{araj} /$ is an indefinite pronoun which refers to only one thing. So, it is thus specified. Syntactically the indefinite pronoun/Raraj/ is modified by a numeral classifier. In this context, the information is already known to the speaker, that is, it is a drawing.

(ii) Examples of indefinite pronouns that occur in the context:

[+specific -known to the speaker - request information]

In this context, the data show that indefinite pronouns frequently occur with a noun modifier or in a subordinate clause. For example:

$$
\begin{aligned}
& \text { ?araj thîi pen khǒn } \\
& \text { what that belong }
\end{aligned}
$$

thónthìn $\mathrm{ca}$ phàan sìi sămkhan
local will past media important tua níi paj thĭn phûuchom $C L$ this go reach audience 'Anything local will reach the audience through this important media.'

Raraj jàan nìn lòn càak what $C L$ one drop from krapăwnən

purse

'Something dropped from a purse.'

In the examples above, the word/Raraj/ is an indefinite pronoun with specificity because it refers to something. Syntactically the indefinite pronoun /Raraj/ is modified by a relative clause or a numeral classifier and thus is a specified entity.

(iii) Examples of indefinite pronouns that occur in the context: [-specific, +negation]

In this context, although an indefinite pronoun occurs with a [-specific] feature, it occurs in a special syntactic structure, as in a sentence with negated predicate. For example:

$$
\begin{aligned}
& \text { lûuk săaw phǒm mâj khəj } \\
& \text { daughter my not ever }
\end{aligned}
$$

paj kháan ใâa ręm thîinăj

go stay overnight where

'My daughter has never stayed overnight anywhere.'

janyaj

$$
\begin{array}{lllr}
\text { chăn mâj rúu ca tham } \\
\text { I not know will do }
\end{array}
$$

how

'I don't know what to do.'

\section{Conclusion}

This study reveals that indefinite pronouns and interrogative pronouns which are homophonous and homographic can be distinguished both syntactically and semantically. Syntactically, interrogative. pronouns can occur freely as an autonomous element in a main clause. Indefinite pronouns, on the other hand, cannot occur in such context but occur in restricted contexts with a noun modifier, a negative element, a yes-no question particle, or as a constituent at a phrase or a clause level.

Semantically, indefinite pronouns can occur in a more general context than interrogative pronouns: indefinite pronouns can occur either in specific or non-specific contexts, and a speaker can either have or not have previous information. Interrogative pronouns, on the other hand, can occur only in a specific context and always require information from the hearer because the speaker does not have any. 


\section{References}

Campbell, R.N. 1969. Noun Substitutes in Modern Thai : A Study in Pronominality. The Hague : Mouton.

Diller, Anthony. 2001. "Grammaticalization and Tai Syntactic Change." In M.R. Kalaya Tingsabadh and Arthur S. Abramson, eds. Essays in Tai Linguistics : 139-176. Bangkok: Chulalongkorn University Press.

Enc, Murvet. 1991. "The Semantics of Specificity." Linguistic Inquiry 22: $1-25$.

Fries, Charles. 1952. The Structure of English. New York. : Harcourt, Brace and Company.

Givón, Talmy. 1979. On Understanding Grammar. New York: Academic Press.

Givón, Talmy. 1984. Syntax : a Functional - Typological Introduction. Vol.1,2. Amsterdam : John Benjamins Pub.Co.

Givón, Talmy. 1989. Mind, code and context : Essays in pragmatics. Hillsdale : Erlbaum.

Haspelmath, Martin. 1997. Indefinite Pronouns. New York: Oxford University Press.

Heine, B., Claudi, U., and Hunnemeyer, F. 1991b. Grammaticalization : A Conceptual Framework. Chicago: The University of Chicago Press.

Hopper, Paul J. 1991. “On Some Principles of Grammaticization." In Traugott, Elizabeth Closs and Heine Bernd, eds. Approach toGrammaticalization Vol.1: 17-35. Amsterdam:John Benjamins Pub.Co.

Kullavanijaya, Pranee. Forthcoming. "A Historical Study of thî̀ in Thai." In Diller, Anthony and Jerold A. Edmondson, eds. The Tai-Kadai Languages. London : Routledge Press.

Kurylowicz, Jerry. 1975. "The Evolution of Grammatical Categories." In
Esquisses Linguistiques II: 38-54. Munchen : Fink Verlag.

Lehmann, C. 1986. "Grammaticalization: and Linguistic Typology." General Linguistics 26:3-21.

Lyons, John. 1969. Introduction to Theoretical Linguistics. Cambridge : Cambridge University Press.

Lyons, John. 1977. Semantics. Vol. 2. London: Cambridge university Press.

Lyons, John. 1995. Linguistic Semantics: An Introduction. Cambridge : Cambridge University Press.

Santaputra, Sirinee. 1984. Structure and Functions of Questions in Thai. Doctoral dissertation, Department of Linguistics, University of Hawaii.

Searle, J. R. 1969. Speech Acts. New York and London: Cambridge University Press.

Traugott, Elizabeth Closs and Heine Bernd, eds. 1991. Approach to Grammaticalization. Vol.1,2. Amsterdam: John Benjamins Pub.Co. 